\title{
A Review of Anti-C Reactive Protein Antibodies in Systemic Lupus Erythematosus
}

\author{
Patricia Richter', Alexandra Burlui', loana Bratoiu', Anca Cardoneanu', Ciprian Rezus², Elena Rezus \\ 1 Department of Rheumatology and Physiotherapy, "Grigore T. Popa” University of Medicine and Pharmacy, lași, Romania \\ 2 Department of Internal Medicine, "Grigore T. Popa” University of Medicine and Pharmacy, Iași, Romania
}

\section{CORRESPONDENCE}

Alexandra Maria Burlui

Str. Universității nr. 16

700115 lași, Romania

Tel: +40 232301615

E-mail: maria-alexandra.burlui@

umfiasi.ro

\section{ARTICLE HISTORY}

Received: April 6, 2021

Accepted: April 28, 2021
Patricia Richter • Str. Universității nr. 16, 700115 Iași, Romania. Tel: +40 232301615 , E-mail: patricia01paty@ yahoo.com

Ioana Bratoiu • Str. Universității nr. 16, 700115 Iași, Romania. Tel: +40 232301615 , E-mail: ioanaharton@ yahoo.com

Anca Cardoneanu • Str. Universității nr. 16, 700115 lași, Romania. Tel: +40 232301615 , E-mail: cardoneanu_ anca84@yahoo.com

Ciprian Rezus • Str. Universității nr. 16, 700115 lași, Romania. Tel: +40 232301 615, E-mail: ciprianrezus@ yahoo.com

Elena Rezus • Str. Universității nr. 16, 700115 lași, Romania. Tel: +40 232301615 , E-mail: elena_rezus@ yahoo.com

\begin{abstract}
Systemic lupus erythematosus (SLE), the prototype autoimmune disease, is characterized by the production of a plethora of autoantibodies with various roles in the development of diseaserelated tissue damage. C-reactive protein (CRP) is an acute phase reactant with a pentameric structure. Under acidic or alkaline conditions, or when urea levels are high and/or calcium levels are low, the pentamer (PCRP) dissociates irreversibly into monomeric CRP (mCRP) and exposes new epitopes (neo-CRP). Importantly, anti-mCRP (but not anti-pCRP) antibodies have been described in patients with SLE, their prevalence varying from $4 \%$ to $78 \%$ in different cohorts. Numerous studies have investigated the relationship between autoantibodies directed against CRP (anti-CRP) and disease activity as well as their association with lupus nephritis (LN), frequently reporting discrepant findings. The main objective of the present review is to describe the role of anti-mCRP antibodies in SLE according to the currently available data.
\end{abstract}

Keywords: systemic lupus erythematosus, lupus nephritis, anti-CRP antibodies, SLEDAI

\section{INTRODUCTION}

Systemic lupus erythematosus (SLE) is considered to be the prototype autoimmune disease in humans. ${ }^{1}$ The pathogenesis of SLE involves the release of a wide range of autoantibodies, inducing extensive tissue damage in multiple organs. ${ }^{2,3}$

C-reactive protein (CRP) is an acute phase reactant of the pentraxin family of serum proteins, known as a serum marker of inflammation..$^{2-5}$ It belongs to the innate as well as adaptive immune system, serving several functions including the efficient removal of apoptotic cells or various antigens and interaction with the complement system.2,4,6 Under acidic or alkaline conditions, or when urea levels are high or calcium levels are low, ${ }^{4}$ the pentamer (pCRP) dissociates irreversibly into monomeric CRP (mCRP) 7 and exposes new epitopes (neoCRP). ${ }^{4,7}$ This process also occurs in vivo in inflamed tissues. ${ }^{8}$ Interestingly, antimCRP but not anti-pCRP antibodies have been described in patients with SLE. ${ }^{8}$ 
TABLE 1. Different prevalence rates of anti-CRP antibodies in SLE and other immune-inflammatory rheumatic diseases

\begin{tabular}{|c|c|c|c|}
\hline References & Patients & $\begin{array}{l}\text { Prevalence of anti-mCRP in } \\
\text { SLE }\end{array}$ & Results \\
\hline Bell et al., 199810 & $\begin{array}{l}50 \mathrm{SLE} \\
40 \mathrm{SCLE} \\
40 \mathrm{DLE} \\
20 \mathrm{SSc} \text { (anti-Scl-70 antibody } \\
\text { positive) } \\
20 \mathrm{SSc} \text { (anticentromere antibody } \\
\text { positive) } \\
20 \text { localized scleroderma } \\
19 \mathrm{PBC} \\
20 \mathrm{EMS} \\
10 \text { bone marrow transplantation- } \\
\text { induced chronic GVHD } \\
40 \mathrm{HC}\end{array}$ & $\begin{array}{l}78 \%(39 / 50) \text { in SLE } \\
30 \%(12 / 40) \text { in SCLE } \\
10 \%(2 / 20) \text { in SSC (anti-Scl-70 } \\
\text { positive) } \\
5 \%(1 / 20) \text { in SSc (anticentromere } \\
\text { positive) } \\
16 \%(3 / 19) \text { in PBC } \\
3 / 40 \text { in DLE without systemic } \\
\text { involvement } \\
\text { O/20 in localized scleroderma } \\
\text { O/10 in GVHD } \\
0 / 20 \text { in EMS } \\
2.5 \%(1 / 40) \text { in HC }\end{array}$ & $\begin{array}{l}\text { Bell et al. found a high prevalence of IgG antibodies } \\
\text { to mCRP in } 78 \% \text { of SLE, but a lower prevalence } \\
(30 \% \text { ) in SCLE patients. } \\
\text { There was no correlation between anti-mCRP with } \\
\text { others antibodies (anti-DNS, anti-Ro, anti-La, anti-U1- } \\
\text { RNP, anti-Sm, anti-histone, anti-CL). }\end{array}$ \\
\hline Minatani et al., 200115 & $\begin{array}{l}125 \mathrm{SLE} \\
24 \mathrm{SSC} \\
16 \mathrm{PM} / \mathrm{DM} \\
77 \mathrm{pSS} \\
102 \mathrm{RA} \\
12 \mathrm{MCTD} \\
49 \mathrm{HC}\end{array}$ & $\begin{array}{l}32 \%(40 / 125) \text { in SLE } \\
22 \%(9 / 24) \text { in SSc } \\
19 \%(3 / 16) \text { in PM/DM } \\
43 \%(33 / 77) \text { in PSS } \\
29 \%(30 / 102) \text { in RA } \\
33 \%(4 / 12) \text { in MCTD } \\
43 \%(3 / 7) \text { in overlap syndrome }\end{array}$ & $\begin{array}{l}\text { Not only patients with SLE, but also other } \\
\text { autoimmune conditions, such as SSc, SS, RA, and } \\
\text { overlap syndrome, presented a high incidence of } \\
\text { anti-mCRP. } \\
\text { A direct correlation was found with other markers } \\
\text { such as serum IgG levels, anti-SS-A, anti-SS-B, and } \\
\text { anti-U1 RNP antibodies. }\end{array}$ \\
\hline Sjöwall et al., $2002^{4}$ & $\begin{array}{l}56 \text { sera with from } 31 \text { anti-dsDNA } \\
\text { positive patients } \\
\text { ( } 27 \text { SLE, } \\
4 \text { autoimmune hepatitis) } \\
16 \text { pSS sera } \\
15 \text { RA } \\
31 \mathrm{CD} \\
37 \cup C\end{array}$ & $\begin{array}{l}48 \%(13 / 27) \text { in SLE on at least } \\
\text { one determination } \\
36 \%(20 / 56) \text { in anti-dsDNA sera } \\
13 \%(2 / 16) \text { in pSS sera } \\
\text { The rest of the patients were } \\
\text { negative. }\end{array}$ & $\begin{array}{l}\text { Sjöwall et al. confirmed the presence of anti-mCRP } \\
\text { in anti-dsDNA antibody positive SLE. } \\
\text { Few anti-CRP positive samples from patients with } \\
\text { pSS. } \\
\text { No positivity for anti-CRP was found in RA, CD, or } \\
\text { UC sera. }\end{array}$ \\
\hline Sjöwall et al., $2004^{16}$ & $\begin{array}{l}10 \mathrm{SLE} \\
100 \mathrm{HC}\end{array}$ & $\begin{array}{l}70 \%(7 / 10) \text { in SLE on at least one } \\
\text { determination }\end{array}$ & $\begin{array}{l}\text { High frequency of anti-CRP in SLE } \\
\text { Positive association with anti-dsDNA antibodies, but } \\
\text { negative with complement factors (C1q, C3, C4) and } \\
\text { lymphocyte count. }\end{array}$ \\
\hline $\begin{array}{l}\text { Rosenau and Schur, } \\
2006^{17}\end{array}$ & $\begin{array}{l}413 \text { patients } \\
\text { (190 SLE, } \\
103 \text { RA, } \\
120 \text { other CTD) } \\
50 \text { HC }\end{array}$ & $\begin{array}{l}23 \%(43 / 190) \text { in SLE } \\
23 \%(23 / 103) \text { in RA } \\
11.6 \%(14 / 120) \text { in other CTD }\end{array}$ & $\begin{array}{l}\text { Presence of anti-CRP in several connective tissue } \\
\text { diseases and inflammatory diseases, including SLE } \\
\text { and RA, but at a lower prevalence than previously } \\
\text { described. }\end{array}$ \\
\hline Figueredo et al., 20061 & $\begin{array}{l}137 \text { SLE } \\
127 \text { non-SLE with persistent aPL } \\
30 \text { idiopathic VTE without APS } \\
80 \mathrm{HC}\end{array}$ & $\begin{array}{l}51 \%(70 / 137) \text { in SLE patients } \\
54 \%(68 / 127) \text { in non-SLE, aPL } \\
\text { positive } \\
5 \%(4 / 80) \text { in } \mathrm{HC}\end{array}$ & $\begin{array}{l}\text { High prevalence of anti-CRP in SLE. } \\
\text { In anti-CRP positive patients, increased levels of } \\
\text { anti-dsDNA and aPL antibodies ( } 52 \% \text { and } 68 \% \text {, } \\
\text { respectively) were detected compared to those } \\
\text { without anti-CRP ( } 26 \% \text { and } 31 \% \text {, respectively). }\end{array}$ \\
\hline Mathsson et al., $2007^{18}$ & $\begin{array}{l}125 \mathrm{SLE} \text { sera } \\
100 \mathrm{HC}\end{array}$ & $40 \%(50 / 125)$ in SLE & $\begin{array}{l}\text { Elevated levels of anti-CRP compared to HC. No } \\
\text { difference between anti-CRP and serum samples } \\
\text { with or without ANA-autoantibodies, high CRP, or } \\
\text { circulating IC. }\end{array}$ \\
\hline $\begin{array}{l}\text { Shoenfeld et al., } \\
200719\end{array}$ & $\begin{array}{l}150 \text { SLE (100 quiescent disease, } \\
50 \text { active disease) } \\
112 \mathrm{HC}\end{array}$ & $\begin{array}{l}10 \% \text { in quiescent disease } \\
4 \% \text { in active disease } \\
4 \% \mathrm{HC}\end{array}$ & $\begin{array}{l}\text { Anti-CRP antibodies were significantly elevated only } \\
\text { in patients with quiescent disease. } \\
\text { Overall, Shoenfeld reported a low prevalence in SLE } \\
\text { patients. }\end{array}$ \\
\hline Kessel et al., $2008^{20}$ & $\begin{array}{l}98 \mathrm{SLE} \\
80 \mathrm{HC}\end{array}$ & $37 \%$ (34/98) in SLE & $\begin{array}{l}\text { High frequency of anti-CRP, but not reaching a } \\
\text { statistical significance }\end{array}$ \\
\hline
\end{tabular}




\begin{tabular}{|c|c|c|c|}
\hline $\mathrm{O}^{\prime} \mathrm{Neill}$ et al., $2010^{8}$ & $\begin{array}{l}39 \text { SLE (high disease activity) } \\
42 \text { SLE (low disease activity) } \\
25 \text { preflare/flare } \\
16 \text { LN } \\
24 \text { SLE with CVD } \\
34 \text { HC }\end{array}$ & $\begin{array}{l}26.3 \% \text { in SLE - high activity } \\
12.8 \% \text { in SLE - low activity } \\
28 \% \text { in preflare/36\% in flare } \\
21.7 \% \text { in SLE with CVD }\end{array}$ & $\begin{array}{l}\text { Anti-CRP levels were higher in SLE patients with } \\
\text { persistent high activity compared to control groups. } \\
\text { They also marked higher at the time of SLE flare. } \\
\text { The first report to establish the presence of anti-CRP, } \\
\text { but also anti-Apo A-I and anti-HDL antibodies in SLE } \\
\text { patients in the } 12 \text { months prior to their CVD event. }\end{array}$ \\
\hline Janko et al., $2011^{21}$ & $\begin{array}{l}39 \mathrm{SLE} \\
35 \mathrm{HC}\end{array}$ & $\begin{array}{l}61.5 \% \text { in SLE } \\
2.7 \% \text { in } \mathrm{HC}\end{array}$ & $\begin{array}{l}\text { A great prevalence of anti-CRP in SLE. } \\
\text { No correlation with anti-dsDNA antibodies. }\end{array}$ \\
\hline Jung et al., $2014^{13}$ & $\begin{array}{l}99 \mathrm{SLE} \\
60 \text { incomplete lupus } \\
48 \mathrm{HC}\end{array}$ & $\begin{array}{l}18 \%(18 / 99) \text { in SLE } \\
8 \%(5 / 60) \text { in incomplete lupus } \\
6 \%(3 / 48) \text { in } \mathrm{HC}\end{array}$ & $\begin{array}{l}\text { Anti-CRP exhibited a positive but weak correlation } \\
\text { with anti-dsDNA antibodies, CRP, and complement } \\
\text { C3, whereas a strong association was seen with } \\
\text { anti-chromatin antibodies. }\end{array}$ \\
\hline
\end{tabular}

HC - healthy controls; anti-CPR - anti C-reactive protein antibodies; SCLE - subacute cutaneous lupus erythematosus; SSC - systemic scleroderma; PBC - primary biliary cirrhosis; GVHD graft-versus-host disease; EMS - eosinophilia-myalgia syndrome; PM/DM - polymyositis/dermatomyositis; MCTD - mixed connective tissue disease; pSS - primary Sjögren's syndrome; RA rheumatoid arthritis; CD - Crohn's disease; UC - ulcerative colitis; CTD - connective tissue diseases; aPL - antiphospholipid antibodies; VTE - thromboembolic disease; APS - antiphospholipid syndrome; IC - immune complex; ANA - anti-nuclear antibody; anti-Apo A-I - anti-apolipoprotein A-I; anti-HDL - anti-high-density lipoprotein; CVD - cardiovascular disease; anti-dsDNA - antidouble stranded DNA antibodies

The presence of anti-CRP autoantibodies in SLE patients was first mentioned by Robey et al. ${ }^{9}$ Bell et al. have described increased levels of anti-CRP antibodies that recognize mCRP subunits. ${ }^{7,10}$ Similarly to other lupus autoantibodies, they can be considered neo-epitope-specific. ${ }^{7}$ Another study showed that amino acids 35-47 represent major epitopes recognized by anti-CRP autoantibodies in lupus nephritis (LN). ${ }^{2}$ Monomeric CRP binds IgG immune complexes (IC) and may have an important role in inflammation and apoptosis. ${ }^{4}$ High levels of anti-mCRP antibodies may reportedly relate to increased SLE disease activity. ${ }^{8}$ Moreover, circulating antibodies directed against CRP together with anti-C1q were suggested to contribute to the pathogenic mechanisms of active LN. ${ }^{7,11}$ Anti-CRP antibodies have been described as potential biomarkers or therapeutic targets in SLE, more particularly in LN. ${ }^{2,12}$ Anti-CRP antibodies are not specific to SLE and are also found in Sjögren's syndrome, rheumatoid arthritis (RA), antiphospholipid syndrome, as well as in children with PFAPA syndrome (Periodic Fever, Aphthous Stomatitis, Pharyngitis, Adenitis). ${ }^{13,14}$

The main objective of the present review is to describe the role of anti-mCRP antibodies in SLE including their relationship with disease activity and lupus nephritis.

\section{ANTI-CRP ANTIBODIES IN SLE AND OTHER AUTOIMMUNE DISEASES}

With respect to the presence of anti-CRP antibodies, studies have demonstrated various prevalence rates in SLE, such as those presented in Table 1. The prevalence of antiCRP antibodies varied between $4 \%$ and $78 \%$. According to the currently available literature data, anti-CRP antibodies may be found in SLE as well as in other autoimmune diseases or healthy individuals. $1,4,8,10,15-17$

Regarding the relationship of anti-mCRP with clinical and laboratory parameters in SLE, Minatani et al. revealed significantly lower levels of anti-CRP in patients with persistent proteinuria, cellular casts, or hypoalbuminemia. ${ }^{15}$ Rosenau and Schur described no association between anti-CRP antibodies and CRP levels or erythrocyte sedimentation rate (ESR), ${ }^{17}$ while Jung et al. observed an inverse correlation with the total platelet count. ${ }^{13}$

Pradhan et al. showed reduced complement levels in anti-CRP positive versus anti-CRP negative Indian patients. ${ }^{22}$ Studying a group of 100 SLE patients with quiescent disease, Shoenfeld et al. reported a positive correlation between anti-CRP and anti-serum amyloid $\mathrm{P}$ protein (SAP), and also between anti-CRP and anti-mannosebinding lectin (MBL). ${ }^{19}$

Jakuszko et al. showed that higher levels of anti-CRP were associated with significantly lower levels of white blood cells. The study also demonstrated that elevated antimCRP levels were associated with notably higher TNF- $\alpha$ levels in SLE. During treatment, a significant decrease in anti-CRP was noted. ${ }^{3} \mathrm{~A}$ research conducted by Figueredo et al. found that the anti-CRP positive patients had a higher frequency of antiphospholipid syndrome (APS), exhibiting a higher frequency of aPL and anti-dsDNA antibodies. Complement C3, C4, and C1q levels were lower in anti- 
TABLE 2. The possible correlation between anti-CRP antibodies and disease activity in SLE

\begin{tabular}{|c|c|c|}
\hline References & Assessment of disease activity & Results \\
\hline Sjöwall et al., $2004^{16}$ & SLEDAI, mSLEDAI & Positive correlations between anti-CRP and disease activity. \\
\hline Figueredo et al., $2006^{1}$ & $\begin{array}{l}\text { Retrospective Systemic Lupus Activity } \\
\text { Measure }\end{array}$ & No association with disease activity. \\
\hline Shoenfeld et al., $2007^{19}$ & ECLAM or SLEDAI score & $\begin{array}{l}\text { No correlation between anti-CRP and disease activity. This may happen } \\
\text { because of the methodology on the determination and cut off levels of } \\
\text { anti-CRP. }\end{array}$ \\
\hline Kessel et al., $2008^{20}$ & SLEDAI & $\begin{array}{l}\text { No notable correlation between the presence of IgG anti-CRP antibodies } \\
\text { and SLEDAl scores. }\end{array}$ \\
\hline Tan et al., $2008^{23}$ & SLEDAI & $\begin{array}{l}\text { Significantly higher SLEDAl rates in patients with anti-mCRP versus those } \\
\text { without. }\end{array}$ \\
\hline O’Neill et al., $2010^{8}$ & BILAG & $\begin{array}{l}\text { Anti-CRP levels were not higher in patients with persistently high disease } \\
\text { activity than in patients with low disease activity. }\end{array}$ \\
\hline Pradhan et al., 201322 & SLEDAI & No statistically significant difference was found in SLEDAl evaluation. \\
\hline Jung et al., $2014^{13}$ & SLEDAI & Anti-CRP presented a weak correlation with the SLEDAI score. \\
\hline Pesickova et al., $2015^{7}$ & SLEDAI & Anti-CRP correlated with the overall activity of SLE. \\
\hline Son et al., 201712 & SLEDAI & No significant correlations were detected with the SLEDAI score. \\
\hline
\end{tabular}

BILAG - British Isles Lupus Assessment Group; ECLAM - European Consensus Lupus Activity; SLEDAI - Systemic Lupus Erythematosus Disease Activity Index; anti-CPR - anti C-reactive protein antibodies

CRP positive lupus patients.1 A notable correlation between the anti-CRP and the mean lupus disease duration has been reported by Son et al. (specifically, longer disease duration corresponded to higher anti-CRP levels). ${ }^{12}$

\section{ANTI-CRP ANTIBODIES AND DISEASE ACTIVITY IN SLE}

Several studies have investigated the presence of serum antibodies directed against $\mathrm{mCRP}$ in patients suffering from SLE and the correlations between the levels of these antibodies and disease activity scores. ${ }^{1}$ As presented in Table 2 , research focusing on the connection between anti-CRP antibodies and SLE activity frequently assessed the latter through the Systemic Lupus Erythematosus Disease Activity Index (SLEDAI), ${ }^{16}$ but also used the British Isles Lupus Assessment Group (BILAG) ${ }^{8}$ and European Consensus Lupus Activity (ECLAM) ${ }^{19}$ indexes.

Some authors found a positive correlation regarding the high levels of anti-CRP and high SLEDAI.7,8,16,23 These results support the relationship between anti-CRP antibodies and disease activity. ${ }^{1,23}$ In contrast, other data suggested that this may not be a useful indicator of disease activity. Jung et al. ${ }^{13}$ reported a weak correlation between the two parameters, while Son et al. ${ }^{12}$ identified no relationship, similarly to the results obtained by Shoenfeld et al. ${ }^{19}$ Pradhan et al. classified SLE patients as having either mild, moderate, or severe disease activity (based on SLEDAI scores) and found no significant difference between these subgroups regarding anti-CRP antibody titers. ${ }^{22}$
Although CRP is a valuable indicator of high disease activity in RA, in lupus patients it may mark the onset of comorbid conditions such as neoplasia and infections. Importantly, high CRP titers in SLE patients require further investigations in order to exclude an overlap syndrome with other autoimmune diseases such as RA or PM. ${ }^{24-26}$ It is considered that CRP is not a useful marker for lupus flares. ${ }^{24}$ Albeit, certain studies have reported a significant relationship between CRP levels and other proinflammatory molecules in SLE, as well as a correlation with disease activity scores. ${ }^{27-30}$ Interestingly, at a genetic level, CRP genotype (rs1205) was negatively correlated with CRP levels and was associated with a lower risk of developing SLE. ${ }^{31,32}$ The significance of high CRP titers and anti-CRP antibodies in active forms of lupus remains requires further investigation. ${ }^{22,33,34}$

\section{ANTI-CRP ANTIBODIES IN LUPUS NEPHRITIS}

Apart from being described in SLE, anti-CRP antibodies seem to be increased particularly in patients with kidney involvement. Several studies have evaluated the possible association between anti-CRP and LN. ${ }^{7,35}$ In this respect, relevant data is shown in Table 3.

It is well known that one of the most severe complications of SLE is renal involvement, being an important cause of morbidity and mortality. ${ }^{71}$ Similarly to anti-dsDNA antibodies, anti-CRP antibodies can bind cellular fragments and necrotic cells, which are then ingested by phagocytes, followed by a release of pro-inflammatory cytokines. ${ }^{6}$ Cer- 
TABLE 3. Anti-CRP antibodies in lupus nephritis

\begin{tabular}{|c|c|c|c|}
\hline Sjöwall et al., 200416 & 10 SLE (4/10 renal involvement) & $100 \%(4 / 4)$ & $\begin{array}{l}\text { All patients with LN tested positive for anti-CRP at } \\
\text { flare. }\end{array}$ \\
\hline Figueredo et al., 20061 & $\begin{array}{l}137 \mathrm{SLE} \\
28 \mathrm{LN} \\
70 \text { anti-CRP positive }\end{array}$ & $27 \%(19 / 70)$ with LN & $\begin{array}{l}\text { In anti-CRP positive patients, the high prevalence of } \\
\text { active nephritis approached a statistical significance } \\
\text { compared to those without. }\end{array}$ \\
\hline Sjöwall et al., 200936 & $\begin{array}{l}38 \mathrm{LN} \\
100 \mathrm{HC}\end{array}$ & $\begin{array}{l}45 \%(17 / 38) \\
16 \%(6 / 38) \text { positive at follow-up }\end{array}$ & $\begin{array}{l}\text { Sjöwall et al. are the first to establish a statistically } \\
\text { significant correlation between anti-CRP and } \\
\text { renal biopsy activity in patients with LN. They also } \\
\text { investigated poor response to therapy. }\end{array}$ \\
\hline Sjöwall et al., 2013"11 & $\begin{array}{l}5 \text { active LN } \\
1 \text { HSP } \\
1 \text { P-i nephritis } \\
1 \text { renal cancer }\end{array}$ & $\begin{array}{l}4 / 5 \text { in } L N \\
O / 1 \text { in HSP } \\
\text { not analyzed in P-i nephritis }\end{array}$ & $\begin{array}{l}\text { Anti-CRP appeared at the highest disease activity of } \\
\text { nephritis; neither before, nor after the flare. }\end{array}$ \\
\hline Jung et al., $2014^{13}$ & $\begin{array}{l}99 \text { SLE (10/99 renal disease) } \\
48 \mathrm{HC}\end{array}$ & absent & $\begin{array}{l}\text { No parallel between anti-CRP and renal involvement. } \\
\text { This may be caused by poor renal manifestations. }\end{array}$ \\
\hline Pesickova et al., $2015^{7}$ & $\begin{array}{l}57 \mathrm{LN} \\
\text { (46 active renal disease, } 11 \\
\text { inactive renal disease,) } \\
29 \text { newly diagnosed LN, } \\
122 \mathrm{HC}\end{array}$ & $\begin{array}{l}26.3 \%(15 / 57) \text { in } L N \\
33 \%(15 / 46) \text { in active } L N \\
0 \%(0 / 11) \text { in inactive renal disease } \\
44.8 \% \text { in newly diagnosed active } \\
\text { LN }\end{array}$ & $\begin{array}{l}\text { Anti-CRP significantly higher in LN versus HC. } \\
\text { Anti-CRP antibodies were detected exclusively in } \\
\text { patients with active renal disease versus inactive } \\
\text { renal disease. }\end{array}$ \\
\hline Son et al., 201712 & $\begin{array}{l}34 \mathrm{SLE} \\
(5 \mathrm{LN}) \\
36 \mathrm{HC}\end{array}$ & $\begin{array}{l}\text { Due to limited number of pa- } \\
\text { tients, anti-CRP linked to LN was } \\
\text { not analyzed }\end{array}$ & No significant correlation with the occurrence of LN. \\
\hline
\end{tabular}

P-i nephritis - pauci-immune nephritis; HSP - Henoch-Schönlein purpura; GN - glomerulonephritis; HC - healthy controls; anti-CPR - anti C-reactive protein antibodies

tain studies have demonstrated experimentally that antiCRP antibodies may be involved in the pathogenesis of LN by interfering with the physiological function of CRP in the clearance of apoptotic debris and in complement activation. ${ }^{5}$ Research performed on biopsy specimens support the link between anti-CRP antibodies and renal biopsy activity index. ${ }^{5,7}$

Pesickova et al. focused on patients with renal involvement (confirmed by biopsy), demonstrating that the prevalence of anti-CRP antibodies in SLE patients was exclusively observed in active LN and not in patients with inactive renal disease. ${ }^{7}$ The study also presented an important negative correlation between anti-CRP and
C3. Elevated levels of anti-CRP were seen in anti-dsDNA positive patients. Moreover, anti-CRP antibodies were significantly associated with unfavorable results (lack of response to treatment, LN flare, or end-stage renal disease) at two years, suggesting their potential role as a marker of active LN.7 This statement comes in accordance with the findings of Sjöwall et al. who described a decrease of antiCRP levels in active $\mathrm{LN}$ patients who were in transition to remission. Additionally, the levels of anti-CRP antibodies were significantly associated with LN activity based on renal biopsy characteristics. ${ }^{36}$ Jakuszko et al. suggested that anti-mCRP antibodies could be a valuable biomarker in $\mathrm{LN}$, which could be used as a prognostic marker in LN. ${ }^{3}$ 
Contrary to the findings reported in the above mentioned studies, Jung et al. detected no correlation with LN. ${ }^{13}$ Similarly, the results obtained by Son et al. did not support the relationship between anti-CRP antibodies and LN. ${ }^{12}$

Ahn et al. stated that CRP levels may be a predictive marker for end-stage renal disease. ${ }^{38}$ Furthermore, it seems that indices such as neutrophil-to-lymphocyte ratio (NLR, demonstrating increased values in LN) and platelet-to-lymphocyte ratio can demonstrate a positive correlation with CRP. ${ }^{39}$ However, whether or not these relationships are maintained in the presence of anti-CRP antibodies (or influenced by the latter) could be a subject of future research.

\section{CONCLUSIONS}

Pentameric CRP experiences conformation changes in vitro but also in vivo in inflamed tissues, giving rise to monomeric CRP. This process also occurs in patients diagnosed with SLE. Albeit a higher prevalence has been reported by certain studies on SLE compared to other autoimmune diseases, anti-CRP antibodies do not meet the criteria for a reliable disease activity or severity. Nevertheless, many studies have reported strong correlations with kidney involvement. Further robust scientific evidence is required to confirm the clinical and prognostic relevance of antimCRP antibodies in SLE.

\section{CONFLICT OF INTEREST}

Nothing to disclose.

\section{REFERENCES}

1. Figueredo MA, Rodriguez A, Ruiz-Yagüe M, et al. Autoantibodies against C-reactive protein: clinical associations in systemic lupus erythematosus and primary antiphospholipid syndrome. J Rheumatol. 2006;33:1980-1986.

2. Li QY, Li HY, Fu G, Yu F, Wu Y, Zhao MH. Autoantibodies against C-reactive protein influence complement activation and clinical course in lupus nephritis. J Am Soc Nephrol. 2017;28:3044-3054.

3. Jakuszko K, Krajewska M, Kościelska-Kasprzak K, et al. Antibodies against monomeric C-reactive protein-a promising biomarker of lupus nephritis? Clin Biochem. 2017;50:756-762.

4. Sjowall C, Eriksson P, Almer S, Skogh T. Autoantibodies to C-reactive protein is a common finding in SLE, but not in primary Sjogren's syndrome, rheumatoid arthritis or inflammatory bowel disease. J Autoimmun. 2002;19:155-160.

5. Dumestre-Pérard C, Clavarino G, Colliard S, Cesbron JY, Thielens NM. Antibodies targeting circulating protective molecules in lupus nephritis: interest as serological biomarkers. Autoimmun Rev. 2018;17:890-899.

6. Doria A, Gatto M. Nephritogenic-antinephritogenic antibody network in lupus glomerulonephritis. Lupus. 2012;21:1492-1496.

7. Pesickova SS, Rysava R, Lenicek M, et al. Prognostic value of anti-CRP antibodies in lupus nephritis in long-term follow-up. Arthritis Res Ther. 2015;17:1-7.

8. O'Neill SG, Giles I, Lambrianides A, et al. Antibodies to apolipoprotein A-l, high-density lipoprotein, and C-reactive protein are associated with disease activity in patients with lupus erythematosus. Arthritis Rheum. 2010;62:845-854
9. Robey FA, Jones KD, Tanaka T, Liu TY. Binding of C-reactive protein to chromatin and nucleosome core particles. A possible physiological role of C-reactive protein. J Biol Chem. 1984;259:7311-7316.

10. Bell SA, Faust H, Schmid A, Meurer M. Autoantibodies to C-reactive protein (CRP) and other acute-phase proteins in systemic autoimmune diseases. Clin Exp Immunol. 1998;113:327.

11. Sjöwall C, Olin Al, Skogh T, et al. C-reactive protein, immunoglobulin G and complement co-localize in renal immune deposits of proliferative lupus nephritis. Autoimmunity. 2013;46:205-214.

12. Son $\mathrm{CN}$, Lee TH, Bang JH, et al. The relationship between anti-C-reactive protein and disease activity in patients with systemic lupus erythematosus. Korean J Intern Med. 2018;33:823.

13. Jung JY, Koh BR, Kim HA, Jeon JY, Suh CH. Autoantibodies to C-reactive protein in incomplete lupus and systemic lupus erythematosus. J Investig Med. 2014;62:890-893.

14. Kraszewska-Głomba B, Myszka M, Krajewska M, Szenborn L. High Prevalence of Autoantibodies Against Monomeric C Reactive Protein (CRP) in Children with PFAPA Syndrome. J Med Biochem. 2018;37:507509.

15. Minatani M, Aotsuka S, Satoh T. Autoantibodies against C-reactive protein (CRP) in sera of patients with systemic rheumatic diseases. Mod Rheumatol. 2001;11:127-131.

16. Sjöwall C, Bengtsson AA, Sturfelt G, Skogh T. Serum levels of autoantibodies against monomeric C-reactive protein are correlated with disease activity in systemic lupus erythematosus. Arthritis Res Ther. 2004;6:R87-94.

17. Rosenau BJ, Schur PH. Antibodies to $\mathrm{C}$ reactive protein. Ann Rheum Dis 2006;65:674-676.

18. Mathsson L, Ahlin E, Sjöwall C, Skogh T, Rönnelid J. Cytokine induction by circulating immune complexes and signs of in-vivo complement activation in systemic lupus erythematosus are associated with the occurrence of anti-Sjögren's syndrome A antibodies. Clin Exp Immunol. 2007;147:513520.

19. Shoenfeld $Y$, Szyper-Kravitz M, Witte T, et al. Autoantibodies against protective molecules--C1q, C-reactive protein, serum amyloid P, mannosebinding lectin, and apolipoprotein A1: prevalence in systemic lupus erythematosus. Ann N Y Acad Sci. 2007;1108:227-239.

20. Kessel A, Rosner I, Halasz K, et al. Antibody clustering helps refine lupus prognosis. Semin Arthritis Rheum. 2009;39:66-70.

21. Janko C, Franz S, Munoz LE, et al. CRP/anti-CRP antibodies assembly on the surfaces of cell remnants switches their phagocytic clearance toward inflammation. Front Immunol. 2011;2:70.

22. Pradhan V, Rajadhyaksha A, Yadav K, et al. Anti-C reactive protein antibodies in Indian patients with systemic lupus erythematosus. Indian J Nephrol. 2013;23:434

23. Tan Y, Yu F, Yang H, Chen M, Fang Q, Zhao MH. Autoantibodies against monomeric $\mathrm{C}$-reactive protein in sera from patients with lupus nephritis are associated with disease activity and renal tubulointerstitial lesions. Hum Immunol. 2008;69:840-844.

24. Schäfer VS, Weiß K, Krause A, Schmidt WA. Does erythrocyte sedimentation rate reflect and discriminate flare from infection in systemic lupus erythematosus? Correlation with clinical and laboratory parameters of disease activity. Clin Rheumatol. 2018;37:1835-1844.

25. Hou $C$, Jin $O$, Zhang $X$. Clinical characteristics and risk factors of infections in patients with systemic lupus erythematosus. Clin Rheumatol. 2018;37:2699-2705.

26. El-Serougy E, Zayed HS, Ibrahim NM, Maged LA. Procalcitonin and C-reactive protein as markers of infection in systemic lupus erythematosus: the controversy continues. Lupus. 2019;28:1329-1336.

27. Atik N, Putri Pratiwi S, Hamijoyo L. Correlation between C-reactive Protein with Malondialdehyde in Systemic Lupus Erythematosus Patients. Int J Rheumatol. 2020;2020:8078412

28. Shaaban A, Helmy M, Barakat M, Elneily D, Ahmed O. Serum resistin, insulin resistance and carotid intima-media thickness as an indication of subclinical atherosclerosis in systemic lupus erythematosus patients. Egypt Rheumatol. 2020. [Epub ahead of print] https://doi.org/10.1016/j. ejr.2020.09.001.

29. Gao D, Shao J, Jin W, Xia X, Qu Y. Correlations of serum cystatin C and hs-CRP with vascular endothelial cell injury in patients with systemic lupus erythematosus. Panminerva Med. 2018;60:151-155.

30. Umare $V$, Nadkarni A, Nadkar $M$, et al. Do high sensitivity C-reactive protein and serum interleukin-6 levels correlate with disease activity in systemic lupus erythematosuspatients? J Postgrad Med. 2017;63:92-95. 
31. Enocsson H, Gullstrand B, Eloranta ML, et al. C-Reactive Protein Levels in Systemic Lupus Erythematosus Are Modulated by the Interferon Gene Signature and CRP Gene Polymorphism rs1205. Front Immunol. 2021;11:3730.

32. Atisha-Fregoso Y, Lima G, Carrillo-Maravilla E, et al. C-reactive protein (CRP) polymorphisms and haplotypes are associated with SLE susceptibility and activity but not with serum CRP levels in Mexican population. Clin Rheumatol. 2018;37:1817-1824.

33. El-Banna HS, El Khouly RM, Gado SE. Elevated serum interleukin-34 level in juvenile systemic lupus erythematosus and disease activity. Clin Rheumatol. 2020;39:1627-1632.

34. Qi S, Chen Q, Xu D, Xie N, Dai Y. Clinical application of protein biomarkers in lupus erythematosus and lupus nephritis. Lupus. 2018;27:1582-1590.

35. Meyer O. Anti-CRP antibodies in systemic lupus erythematosus. Joint Bone Spine. 2010;77:384-389.
36. Sjöwall C, Zickert A, Skogh T, Wetterö J, Gunnarsson I. Serum levels of autoantibodies against C-reactive protein correlate with renal disease activity and response to therapy in lupus nephritis. Arthritis Res Ther. 2009;11:1-9.

37. Yang XW, Tan Y, Yu F, Zhao MH. Interference of antimodified C-reactive protein autoantibodies from lupus nephritis in the biofunctions of modified C-reactive protein. Hum Immunol. 2012;73:156-163.

38. Ahn SS, Yoo J, Jung SM, Song JJ, Park YB, Lee SW. Comparison of clinical features and outcomes between patients with early and delayed lupus nephritis. BMC Nephrol. 2020;21:1-9.

39. Soliman WM, Sherif NM, Ghanima IM, El-Badawy MA. Neutrophil to lymphocyte and platelet to lymphocyte ratios in systemic lupus erythematosus: Relation with disease activity and lupus nephritis. Reumato/ Clin. 2020;16:255-261. 